\author{
Анђелија Пругинић \\ Градска библиотека \\ „Карло Бијелицки”, Сомбор \\ pruginicandja@yahoo.com
}

Оригиналан научни рад

UDK 316.644-055.5:028.5(497.113)

027.022-053.5(497.113)

https://doi.org/10.18485/bibliotekar.2019.61.1.3

\title{
ЗНАЊЕ ЈЕ У КЊИГАМА, КЊИГЕ СУ У БИБЛИОТЕКАМА. ГДЕ СУ ЉУДИ?
}

Сажетак: Рад је настао као резултат истраживања на тему читања, чланства, посета библиотеци и др. у циљу подстицања читања и повећања броја корисника библиотеке. Статистике су сурова мерила и чињенице и не можемо и не смемо их занемарити. Немамо изговоре. Да бисмо дошли до неgосеїнуйих корисни$\kappa a$, спровели смо истраживање чији су нам резултати дали смернице за даље унапређивање библиотечког пословања. Осмислили смо неколико пројеката, од којих су два већ актуелна и активна: пројекат Можеш йозајмийи књиїу сваку,

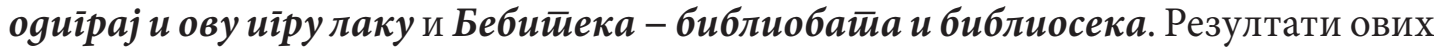
пројеката су већ видљиви и мерљиви.

Кључне речи: деца, читање, иновације, корисници, истраживање, идеје, креативне радионице, мотивационо читање.

\section{Увод}

Према библиотечким стандардима, број уписаних корисника у библиотеку требало би да обухвати $12 \%$ од укупног броја становника града/ општине, а Сомборска библиотека има 5\% корисника.

Важно је напоменути да смо од 2008. године аутоматизовали позајмицу библиотечке грађе, све књиге су електронски обрађене у систему COBISS, постоји онлајн могућност прегледа каталога, резервација, продужења рока задржавања књига итд. Организујемо и неколико књижевних манифестација, промоције, предавања, семинаре, радионице за децу, трибине, разноврсна гостовања. Фонд је богат, разноврстан, доступан корисницима. 
Сва деца у граду која похађају предшколску установу и први разред основне школе уписана су бесплатно (иначе су бесплатни уписи до 2. разреда основне школе). Уписивање се врши по списковима, групама и деца долазе у библиотеку са васпитачицама и учитељима по чланске картице и том приликом им се приреди адекватна радионица. Постоје и разни попусти за одређене категорије чланова (пензионери, добровољни даваоци крви, корисници социјалне помоћи, особе са посебним потребама...).

Библиотека је у претходној години забележила 6.127 посета различитим програмима и садржајима, што је у просеку око 500 месечно. Ту улазе програми и за децу и за одрасле, пошто се одржавају у згради Дечјег одељења. Више од просека бележи се у месецу мају и октобру (конкретно у мају због премијере и две репризе представе за децу Црвенкайа коју смо реализовали по пројекту Og израgе луйке gо gрамске иірре, за који смо добили средства од Министарства културе и информисања Републике Србије; у октобру због Дечје недеље и свакодневних радионица и промоција). Све наше програме оглашавамо на друштвеним мрежама, у локалним медијима и на сајту Дечјег одељења - http://www.biblionica.rs/, неке програме само најављујемо, неке објављујемо као вест, а неки програми захтевају и једно и друго.

\begin{tabular}{|l|}
\hline Статистика за 2018. годину: \\
\hline 2.530 уписаних \\
\hline 1.655 на Позајмном одељењу \\
\hline 875 на Дечјем \\
\hline 471 предшколаца \\
\hline 409 основна школа \\
\hline 173 средња школа \\
\hline 177 студената \\
\hline 329 пензионера \\
\hline 172 незапослени \\
\hline 527 запослени и др. \\
\hline
\end{tabular}

Где су остали потенцијални корисници? Како децу од најмлађег узраста мотивисати, подстаћи на читање? Да ли ђаци (уопште) читају само 
школску лектиру и да ли им је фонд школске библиотеке довољан? Како побољшати комуникацију ПОРОДИЦА - ВРТИЋ - ШКОЛА - БИБЛИОTEKA? (Дешава се да родитељи не знају да су им деца уписана у библиотеку!) Који корак који од детета прави љубитеља књиге је најважнији?

Статистика показује да се значајно смањује број чланова приликом преласка из основне у средњу школу, односно приликом преласка са Дечјег одељења на Одељење одраслих. Зашто?

\section{Како је спроведено истраживање}

На основу ових и многих других параметара и чињеница, дошли смо на идеју да спроведемо једно стручно, свеобухватно истраживање, чији резултати би нам указали где је горући проблем, где би највише требало обратити пажњу, где то шкрийи у нашем пословању. Наравно, ми смо само једна карика у ланцу, али врло важна и неопходна у развоју читалачких навика код деце. Породица, школа, предшколске установе, друштвена заједница, медији итд. - све су то фактори који утичу на личност детета у сваком смислу, па и на наклоност према књизи и читању. ${ }^{1}$ Деце никад доста, читања такође. Имамо и децу и књиге, имамо лепу и савремено уређену библиотеку, људе од знања, па ипак... Децу ни најмање не можемо кривити што не долазе чешће у библиотеку и што не читају више.

У сарадњи са нашом библиотеком истраживање је обавио Психолошки центиар за саветиоваюе, еgукацију и истираживаюе - СЕЛФ, из Новог Сада. Оно је обухватило, пре свега, две радионице у којој су учествовала деца нижих и виших разреда основне школе, формиране као две фокус групе, на основу којих су прављене анкете. Радионице су организоване и одржане на Дечјем одељењу сомборске библиотеке. Једна врста анкете је била намењена деци нижих разреда основне школе, коју су попуњавали са родитељима, а друга за децу виших разреда, која су анкету попуњавала сама. Овим истраживањем биле су обухваћене све основне школе у Сомбору, њих пет, по једно одељење из сваког разреда, укупно 511 ученика.

Павле Илић, Оливера Гајић и Миланка Маљковић, Криза чийаюа: комйлексан йеgаїошки,

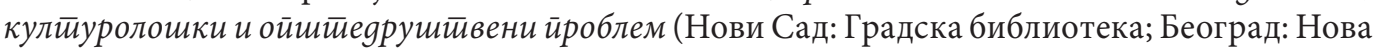
школа, 2008), 20-22. 


\section{Анализа истраживања ${ }^{2}$}

\section{Виши разреgи}

Опис узорка:

Узорак испитаника чинило је 268 ученика виших разреда основних школа у Сомбору, просечне старости од 12,33 године, у распону од 10 до 15 година. Испитаници су били уједначени по полу (50,5\% дечака), од којих су $69,3 \%$ испитаника чланови библиотеке. Око половине оних који нису чланови библиотеке имају жељу да у будућности постану чланови. У просеку су први пут постајали чланови библиотеке са 7 година (распон од 3 до 14).

Учесталост долазака у библиотеку:

Веома мали број испитаника (3\%) долази у библиотеку једном недељно или чешће, док њих преко 70\% библиотеку посећује свега неколико пута годишње. Њих око 50\% овакву учесталост долажења у библиотеку објашњава тиме што књиге набавља на друге начине (куповина, читање на интернету, кућна библиотека и сл.), док њих око 40\% нема навику да чита или не стиже да се бави читањем. Њих $12 \%$ сматра да библиотека није довољно опремљена књигама које би они позајмљивали. Упркос томе, велики број испитаника даје бројне предлоге који би по њиховом мишљењу допринели томе да библиотека постане атрактивније место за долазак. По овоме можемо претпоставити да одлажење у библиотеку није у потпуности отписана могућност за велику већину, односно да већина испитаника показује намеру да чешће долази у библиотеку уз одређене допуне или измене у садржајима.

Навике и ставови о читању:

Укупно 23,8\% испитаника се изјаснило да не воли да чита, али се нада да ће некад заволети читање, док $28 \%$ испитаника сматра да би неке промене у библиотеци могле да допринесу томе да чешће долазе. Када овоме додамо податке из претходног пасуса да њих 12\% сматра да библиотека није довољно опремљена, као и да сами предлажу бројне предлоге како унапредити број посета библиотеци, можемо размишљати о практичним импликацијама које нам ови подаци нуде. У првом реду ово се односи на креирање програма који би омогућили корисницима да учествују у предлозима око набавке књига, осмишљавању садржаја у библиотеци који би њима били занимљиви и сл. На тај начин би се омогућило ученицима да

Анализу спроведеног истраживања урадио је стручни тим Психолошкої ценйра за саве-

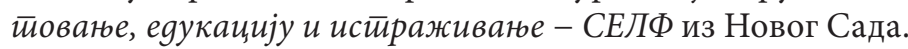


партиципирају у креирању садржаја који су њима намењени што се показује као важан фактор у адекватном приближавању садржаја корисницима.

Уочена је и контрадикторност између начелних ставова о књигама и спремности да се чита и посећује библиотека. Наиме, већина испитаника доживљава читање као инспиративно, едукативно, забавно итд. али исто тако, многи од њих наводе да претежно читају лектиру коју доживљавају као незанимљиву, односно застарелу. Лектира је уједно и оно што испитаници најчешће позајмљују из библиотеке. Имајући у виду ове налазе, смерница би била да се акценат стави на осмишљавање начина да се корисницима представе или приближе књиге које библиотека поседује мимо лектире, а намењене су њиховом узрасту, као и да се освежи фонд књига које нису лектира.

На основу питања о родитељском односу према читању, примећује се да мајке више читају књиге као вид опуштања, као и да су склоне да чешће посећују библиотеку од очева, који с друге стране чешће немају времена или навику да слободно време проводе читајући. Међутим, у апсолутним вредностима, и мајке и очеви релативно ретко посећују библиотеку. Са овим родитељским ставовима и навикама су вероватно повезани и резултати који нам говоре да девојчице у нашем узорку имају израженији позитивни однос према читању, као и да позитивнији став према читању имају деца чији родитељи читају као вид опуштања, редовно одлазе у библиотеку и имају навику да читају.

Однос према услугама библиотеке:

Корисници су највише упознати са услугама библиотеке које се тичу организовања радионица, промоција књига, као и могућности коришћења читаонице. Око половине корисника је упознато и са осталим садржајима библиотеке. Преко 65\% испитаника сматра да би сада, када су упознати са овим додатним садржајима библиотеке, барем делимично користили те услуге. Међутим, њих 30\% наводи да није заинтересовано да чешће посећује библиотеку ни након што је упознато са свим њеним услугама. Важно би било осмислити начине да се овај део потенцијалних корисника заинтересује за долазак у библиотеку. За њих вероватно само добијање информације о садржајима није довољно мотивишуће, па би било корисно доћи до информација шта би њих привукло да чешће долазе у библиотеку. Ово се нпр. може добити организовањем фокус група или радионицама са децом која ретко долазе у библиотеку.

Процена библиотечких услуга је углавном позитивна, библиотекари су већински доживљени као компетентни и љубазни, иако је најниже оцењена улога библиотекара као некога ко мотивише кориснике да више 
читају. Уз то само 19\% ученика мисли да библиотекари могу да допринесу њиховом чешћем одласку у библиотеку. Ове податке можемо да искористимо као повратну информацију, односно као подстицај за осмишљавање начина како остварити већи домет библиотекара у улози некога ко је у позицији да промовише читање као занимљиву и трајну вредност. Резултати који нам говоре о важности улоге библиотекара кажу да позитивнији однос према читању имају они ђаци који виде спремност библиотекара да помогне у одабиру књиге, који је љубазан и пружа корисне информације.

\section{Нижи разреgи}

Опис узорка:

Узорак испитаника чинило је 243 ученика нижих разреда основних школа у Сомбору, просечне старости од 8,5 година, у распону од 6 до 11 година. Испитаници су били уједначени по полу (52,1\% девојчица). Највећи број родитеља оцењује свој економски статус као задовољавајући или добар. Више од пола родитеља имају средњу стручну спрему, затим следи група родитеља са вишом школом или факултетом, док је убедљиво најмање оних са завршеном основном школом. Седамдесет пет процената родитеља извештава да је њихово дете тренутно корисник библиотеке и да је у просеку први пут постало корисник библиотеке са 5,8 година (распон од 2 до 9 година).

Учесталост долазака у библиотеку:

Веома мали број испитаника (2\%) долази у библиотеку једном недељно или чешће, њих око $42 \%$ иде у библиотеку једном месечно или чешће, док њих преко 56\% библиотеку посећује свега неколико пута годишње или ређе. Скоро $50 \%$ родитеља овакву учесталост долажења у библиотеку објашњавају тиме што књиге деци набављају на друге начине (куповина, кућна библиотека и сл.), док њих око 22\% нема навику да чита или не стиже да доводи дете у библиотеку. Њих преко 33\% наводи да њихова деца нису заинтересована да читају мимо онога што је задато у школи. Свега 29,8\% родитеља је веома задовољно тиме колико им деца читају, $54,3 \%$ родитеља би волело када би им се деца више занимала за књиге, док је 11,6\% родитеља незадовољно временом које им дете проводи читајући. Као одговорне за такво стање родитељи виде себе (не стижемо да читамо и дамо пример), као и наставнике, односно школу, медије, вршњаке итд. Уз то, већина родитеља даје бројне предлоге (набројани у извештају) који би по њиховом мишљену допринели томе да библиотека постане атрактивније место за долазак. На основу овога можемо претпоставити да родитељи ипак сматрају да би одређене иновације у функционисању библиотеке допринеле већој посети. 
Навике и ставови о читању:

За разлику од ученика виших разреда, испитаници из узорка нижих разреда из библиотеке осим лектире са значајном учесталошћу читају још и бајке, кратке приче, пустоловине и басне.

Родитељи већински сматрају да је важно доводити децу у библиотеку, да библиотека нуди пуно занимљивог садржаја, да су библиотекари љубазни и предусретљиви, али и да су с друге стране деца преоптерећена школским и ваншколским обавезама, као и да ни они сами често немају времена да децу доводе у библиотеку.

Што се тиче читалачких навика код родитеља, слично као и на узорку ученика виших разреда, примећује се да мајке више читају књиге као вид опуштања, као и да су склоне да чешће посећују библиотеку од очева, који с друге стране чешће немају времена или навику да слободно време проводе читајући. Такође, у апсолутним вредностима, и мајке и очеви релативно ретко посећују библиотеку. Међутим, интересантан налаз је да већина родитељских карактеристика није повезана са учесталошћу долазака деце у библиотеку, па тако једнако често долазе деца чији су родитељи различитог степена образовања, те једнако често посећују библиотеку без обзира на понашање учитеља и родитеља. Насупрот томе, изгледа да је за ову популацију понашање библиотекара важно, с обзиром на то да чешће у библиотеку долазе деца која имају позитивнији став према библиотекарима и боље искуство са њима, као и она деца која су упозната са разним садржајима у библиотеци.

Однос према услугама библиотеке:

Родитељи су највише упознати са услугама библиотеке које се тичу организовања радионица, промоција књига, као и могућности коришћења читаонице. Нешто мање су упознати и са осталим садржајима библиотеке. Преко 85\% испитаника сматра да би сада, када су упознати са овим додатним садржајима библиотеке, барем делимично посећивали, односно користили те услуге. Међутим, њих преко 13\% наводи да не би чешће посећивали библиотеку ни након што је упознато са свим њеним услугама. Делимично је овакво стање неупућености у садржаје библиотеке, као и неспремности једног мањег броја родитеља да доводе децу могуће објаснити тиме да њихова деца тек постају чланови или су кратко учлањени у библиотеку, односно да ће се временом боље упознати са радом и стећи навику довођења деце у библиотеку. Било би корисно евентуално осмислити и садржаје којима би се сами родитељи привукли да долазе у библиотеку са децом, кроз нпр. радионице о родитељству. 
Процена библиотечких услуга је претежно позитивна, библиотекари су већински доживљени као компетентни и предусретљиви. Као на узорку виших разреда, и овде је најниже оцењена улога библиотекара као некога ко мотивише кориснике да више читају (у апсолутним мерама и ово је висока оцена, 3,38 од 4, али у поређењу са осталим карактеристикама, ово је најнижа оцена). Иако родитељи не сматрају у великом броју да је утицај библиотекара пресудан фактор за мотивацију деце да више посећују библиотеку (само њих 71 мисли да јесте важан утицај библиотекара), већ наведени подаци (чешће у библиотеку долазе деца која имају позитивнији став према библиотекарима и боље искуство са њима, као и она која су упозната са разним садржајима у библиотеци) нам указују супротно. За децу нижих разреда је очигледно важно какав однос су изградила са библиотекарима, што нам указује да је потенцијалан утицај библиотекара на формирање читалачких навика у овом узрасту још већи него на каснијем узрасту. То може указати на важност осмишљавања додатних библиотечких програма за децу овог узраста како би изградили и развили адекватне читалачке навике и одржали их и у вишим разредима школовања.

Генерално гледано, резултати добијени овим истраживањем могу да послуже, осим као начин да се евалуира тренутно стање по питању читалачких навика и степена коришћења услуга библиотеке на узорку ученика основних школа, и као водич за осмишљавање стратегије унапређења рада библиотеке. Уколико библиотека осмисли и спроведе неке од предложених мера које сами корисници предлажу, или пак на основу ових предлога осмисли стратегију са циљем повећања броја корисника, већег укључивања већ постојећих корисника, изградњи већег поверења корисника према услугама итд., ово истраживање такође може да користи као прво мерење у провери ефикасности мера које би таква стратегија укључивала. Поређењем ових резултата и резултата поновљеног истраживања у одређеном временском интервалу након примене потенцијалних нових мера би могли да видимо да ли су дате мере постигле жељени ефекат. 


\section{Новине у раду дечјег одељења}

ИФЛА смернице за библиотечке услуге за децу врло јасно одређују циљ и сврху јавних библиотека и можемо рећи да их у великом делу пратимо и испуњавамо, у мери у којој је то могуће у нашим условима. Када кажемо нашим, мислимо на окружење у којем живимо, систем, државу, стање у култури, Србију као земљу у развоју. ${ }^{3}$ Оно што је суштина ових смерница, а подудара се са неким од закључака истраживања, јесте да децу треба подстицати да од малих ногу користе библиотеку, јер се тиме повећава вероватноћа да ће и у будућности остати њени корисници. Кључне речи су: КОРИСНИЦИ, КОРИСТИТИ, БИБЛИОТЕКА!

„Задовољавање потреба корисника остаје суштина библиотечких услуга, шта год друго оне радиле"

Да не бисмо губили драгоцено време предузели смо већ неке кораке у маркетингу да бисмо били што видљивији, интересантнији и прихватљивији нашим корисницима, пре свега деци. На стази која води до улаза у зграду Дечјег одељења исцртана је игра школице којој претходи саобраћајни знак у виду обавештења, на којем пише: Можеши йозајмийи књиі̄y свакy, a oguīpaj и ову иїру лакy! Овај пројекат спроведен је у сарадњи са ликовним студиом Винсент и предузећем Сигнал из Сомбора. Облик, форма, боје овог иіроказа привлаче пажњу свих пролазника, а највише деце којој је и намењен.

Од 1. маја 2019. кренућемо у реализацију пројекта Бебитека - библиобата и библиосека. У сарадњи са градском болницом и под покровитељством приватне сомборске фирме Метеор-Комерц обезбедили смо, за сада, поклон књиге за сваку прворођену девојчицу и дечака у месецу и бесплатну годишњу породичну чланарину (за мајке). Намера нам је да у будућности омогућимо исто то свим новорођеним бебама у сомборској болници (општини). Чињеница је да се навика читања ствара у кући, у породици и библиотека као важан фактор у неговању тих навика жели

3 Павле Илић, Оливера Гајић и Миланка Маљковић, Криза чийаға: комйлексан йеgаїошки,

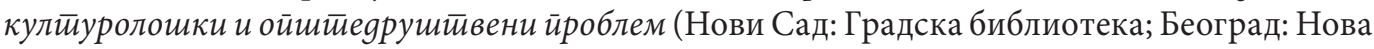
школа, 2008), 20-22.

4 Анализу спроведеног истраживања урадио је стручни тим Психолошкоі цеенитра за саветиоване, еgукацију и истираживане - СЕЛФ из Новог Сада.

5 IFLA. „Смернице за библиотечке услуге за децу”. Гласник Нароgне библиоиеке Србије год. 8, бp. 1 (2006): 205-209. 
да на овај начин подстакне и промовише књигу и читање. Искуство као и спроведено истраживање, показало нам је да је породица кључни фактор, те смо се због тога и усмерили на породицу нашим деловањем. Наравно, на дуге стазе, верујући у значајне резултате за неколико година.

\section{Библиотека на отвореном}

Библиотека на отвореном са соларним напајањем представља савремен вид размене књига. Подразумева да свако може да донесе књиге и допуни фонд библиотеке, да свако може да узме књигу и врати је након читања. Прву грађу библиотеке чине публикације за све узрасте, различитих жанрова и на више језика (српски, мађарски, хрватски). Циљ нам је да Библиотека на отвореном постане место окупљања грађана Сомбора, највише младих, где ће им на једном месту уз бесплатан приступ интернету бити понуђен богат избор књига и часописа.

Уз полице за књиге, које су заштићене од атмосферских утицаја, елемент поседује три УСБ пуњача за допуну мобилних уређаја, као и 4 Г вај-фај или вајрлес рутер за интернет. Цео систем се напаја електричном енергијом из сопственог соларног система. Њено постављање предвиђено је на фреквентном месту у центру града Сомбора, на Тргу уметности, који се налази између Народног позоришта Сомбор, Градског музеја Сомбор и Дечјег одељења Градске библиотеке.

Свака нова активност је и маркетиншки добро осмишљена, јер је данас, без рекламирања онога што радите, тешко допрети до корисника, потрошача, конзумената...

\section{Закључак}

Емпиријско сазнање да пред сваком библиотеком стоје две групе људи: мања - стварни корисници библиотечких услуга и већа - могући и очекивани корисници библиотечких услуга, суштина је и порука овог рада. За библиотеку су обе групе једнако важне и то је оно што библиотечку струку чини особеном и свима потребном. Тако улога библиотеке постаје већа и значајнија у формирању библиотечке публике. Она мора бити видљивија, отворенија и мора бити стуб око којег ће се окупљати све значајне институције које се на било који начин баве децом. И не само институције већ и појединци, групе грађана, невладине организације, 
успешан приватни сектор и пре свих - породица као најјача карика у стварању многих, па и читалачких навика код деце. С том идејом и намером усмеравамо своје нове активности - подизање свести људи, родитеља пре свега, о значају породичног читања, о значају књиге и коришћења библиотечких услуга.

Сомборска библиотека има добар рејтинг у граду као најстарија установа културе и то доказује дугогодишња сарадња са различитим установама: предшколском установом „Вера Гуцуња”, основним и средњим школама, нарочито Гимназијом „Вељко Петровић”, Сомборским едукативним центром - СЕЦ, Народним позориштем, Културним центром „Лаза Костић”, Градским музејем, многим приватним предузећима, које су нам и сарадници, покровитељи, подршка и инспирација. Свима нама је исти заједнички именитељ - формирање и неговање културе читања код деце и омладине.

Наставићемо да са новим програмима и садржајима оплемењујемо и свој рад и свој град. Један од следећих корака ће бити ново истраживање, којим бисмо обухватили не баш мали проценат деце (око 30\%) која уопште не користе услуге библиотеке, и које ће нам показати резултате свих горе поменутих иновација и пројеката, да видимо шта смо успели да урадимо.

Криза читања је глобалног карактера и свако од нас ко се бави књигом на било који начин мора да делује локално што је могуће више, да бисмо је ублажили и превазишли. Наша професија је и мисија, наш језик је универзалан и те предности би требало искористити на прави начин и бити свестан привилегије коју тиме имамо - радити са децом, бити им ментор, узор, пријатељ, имати шансу да им омогућимо лични развој и напредак, можда их и усмерити на избор будућег занимања. Важно је осећати се добро и испуњено у послу који радиш, а ми се добро осећамо када знамо да смо урадили баш све што смо могли, без резерве, без задршке. Када деца то осете код свих нас, долазиће, читаће, посећиваће библиотеку и када им књига није потребна. Тада ћемо знати да смо успели. Да је вредело. Да може. 


\section{Literatura:}

1. Božić, Jadranka. „Antropologija knjige i čitanja”. Glasnik Narodne biblioteke Srbije god. 1, br. 1 (1999): 113-145. (na ćirilici)

2. Brofi, Piter. Biblioteka u dvadeset prvom veku: nove usluge za informaciono doba. Beograd: Clio, 2005.

3. Vučković, Željko i Nada Todorov. Kultura čitanja u vremenu interneta. Inđija: Narodna biblioteka „Dr Đorđe Natošević”, 2010. (na ćirilici)

4. Župan, Vesna. Marketing u bibliotekama. Beograd: Svet knjige, 2001. (na ćirilici)

5. Ilić, Pavle, Olivera Gajić i Milanka Maljković. Kriza čitanja: kompleksan pedagoški, kulturološki i opštedruštveni problem. Novi Sad: Gradska biblioteka; Beograd: Nova škola, 2008. (na ćirilici)

6. Injac-Malbaša, Vesna. E-biblioteka. Beograd: Clio, 2016.

7. IFLA. „Smernice za bibliotečke usluge za decu”. Glasnik Narodne biblioteke Srbije god. 8, br. 1 (2006): 205-209. (na ćirilici)

8. IFLA. „Smernice za bibliotečke usluge za mlade”. Glasnik Narodne biblioteke Srbije god. 8, br. 1 (2006): 211-217. (na ćirilici)

9. Mangel, Alberto. Biblioteka noću. Beograd: Geopoetika, 2008.

10. Mangel, Alberto. Istorija čitanja. Novi Sad: Svetovi, 2005.

11. Milutinović, Ivana. „Mladi u biblioteci zahtevni i zahvalni”. Savremena biblioteka god. 18, br. 23 (2006), 24-25. (na ćirilici)

12. Novaković, Katarina i Dragana Božić. „Od deteta do aktivnog čitaoca: programi namenjeni mladim korisnicima Dečjeg odeljenja Gradske biblioteke u Novom Sadu”. U Tinejdžeri - zahtevni korisnici i biblioteke za nove generacije: zbornik radova sa međunarodnog stručnog skupa održanog u Lazarevcu, 15-16. septembra 2015, priredila Milica Matijević, 99-108. Lazarevac: Biblioteka „Dimitrije Tucović”, 2015. (na ćirilici)

13. „Pravilnik o nacionalnim standardima za obavljanje bibliotečko-informacione delatnosti”. Službeni glasnik RS br. 39 (2013). (na ćirilici)

14. "Zakon o bibliotečko-informacionoj delatnosti”. Službeni glasnik RS br. 52 (2011). (na ćirilici) 


\author{
Anđelija Pruginić \\ City Library „Karlo Bijelicki”, Sombor \\ pruginicandja@yahoo.com
}

\title{
THE KNOWLEDGE IS IN THE BOOKS, THE BOOKS ARE IN THE LIBRARIES. WHERE ARE THE PEOPLE?
}

\begin{abstract}
This paper is the result of the research on reading, membership, and library visits in order to encourage reading and increase the number of library users. The statistics are harsh and facts cannot be ignored. There are no excuses. In order to reach the unreached users, we have conducted a research the results of which provided guidelines for improvement of library management. We have designed several projects, two of which have already been implemented: You can loan every book, play the game in our nook and Baby library - Biblio-boy and Biblio-girl. The results of these projects are already visible and measurable.
\end{abstract}

Keywords: children, reading, innovation, users, research, ideas, creative workshops, reading motivation.

Примљено: 11. априла 2019.

Прихваћено: 21. маја 2019. 